\title{
Clones with New Phenotypes through Transformation of Bacillus brevis 47, a Protein-producing Bacterium
}

\author{
Iffat Hussain, Norihiro TsuKagoshi and Shigezo UDAKA* \\ Department of Food Science and Technology, Faculty of Agriculture, \\ Nagoya University, Chikusa-ku, Nagoya 464, Japan
}

Received March 2, 1981

\begin{abstract}
Bacillus brevis No. 47, a high protein producer, was treated with deoxyribonucleic acid (DNA) from different strains of $B$. subtilis and B. amyloliquefaciens, the latter being an efficient producer of extracellular enzymes such as $\alpha$-amylase, protease and ribonuclease (RNase). From the new clones obtained by the transformation procedure, about eighty were purified and used for examining the productivity and nature of trichloroacetic acid precipitable extracellular proteins, and the levels of activities and characteristics of $\alpha$-amylase, protease and RNase secreted into the extracellular medium. The incorporation of various donor genetic markers into the new clones was also examined.

Despite little homology between the donor and the recipient DNAs, the appearance of the new clones was most probably the result of donor DNA mediated recombination events, because these clones exhibited unpredictably diverse combinations of phenotypes (e.g., extracellular enzyme activities or expression of donor markers). Among the recombinant clones obtained were those which produced greater amounts of extracellular proteins or possessed many-fold higher extracellular enzyme activities than their respective parents. The results presented in this paper show the usefulness of heterologous transformation for obtaining bacteria with new and varied phenotypes.
\end{abstract}

Bacillus brevis No. 47, which was isolated in this laboratory, ${ }^{1)}$ is an excellent producer of proteins. When grown in a nutrient rich medium at $34^{\circ} \mathrm{C}$ large amounts of protein (12 $\mathrm{mg} / \mathrm{ml}$ ) can be obtained from the culture supernatant. ${ }^{2)}$ Except for a weak protease activity, no other enzyme activity was so far detected in the culture fluid. Such a nature makes this organism particularly suitable for studying the mechanism of protein excretion and for use as a host in genetic engineering. For these studies we needed to know the genetic background of this organism which was entirely unknown.

As a first step to manipulate $B$. brevis 47 genetically, we tried to transform the organism with heterologous DNA. B. amyloliquefaciens, an efficient producer of exoenzymes such as $\alpha$ amylase and protease, and also $B$. subtilis (Marburg strain) were used as DNA donors. In spite of the fact that there is little homology

* To whom all correspondence should be addressed. between the DNA of these donors and the DNA of $B$. brevis, this study was undertaken in order to explore the possibility that useful recombinants could be obtained through transformation and not by gene engineering. An immediate aim of this study was to obtain high enzyme producers among the resulting recombinants.

\section{MATERIALS AND METHODS}

Bacterial strains. B. brevis $47-5$ is a uracil requiring mutant derived from $B$. brevis No. 47. ${ }^{1)}$ B. amyloliquefaciens F ATCC 23350 was obtained from Ajinomoto Co. The following strains were kindly supplied by Dr. H. Saito (Inst. of Applied Microbiol., University of Tokyo): B. subtilis PS909, purB $B_{6}$ thr $_{5}$ met $B_{5}$ hisA lys leu $_{8}$ $\operatorname{trp}_{2}$ rif $^{r}$ str $^{r}$, B. subtilis YS11, purB $B_{6} \operatorname{leu}_{8} \arg _{15}$ and $B$. amyloliquefaciens $\mathrm{K}(\mathrm{M} 1331)$ met his arg leu str $^{r}$. Other auxotrophic mutants of $B$. brevis No. 47 were from the collection of this laboratory.

Media. Recipient B. brevis 47-5 and new clones were routinely grown in nutrient medium $\mathrm{T} 2^{1)}$ (supplemented with $0.005 \%$ uracil), for protein and enzyme production. 
Growth medium (GM) and competence medium $(\mathrm{CM})^{3)}$ with modifications were used for transformation experiments. Arginine was omitted from the media and other modifications were as follows: $\mathrm{K}_{2} \mathrm{HPO}_{4}(0.1 \%), \mathrm{KH}_{2} \mathrm{PO}_{4}$ $(0.04 \%)$, Na-citrate $(0.01 \%)$. GM and CM were supplemented with $30 \mu \mathrm{g} / \mathrm{ml}$ of uracil, respectively.

Preparation of DNA. Donor DNA from B. subtilis and $B$. amyloliquefaciens strains was prepared according to the phenol-pH 9 method of Saito and Miura. ${ }^{4)}$

Transformation. Preliminary studies with homologous DNA were done in order to find out if, at all, B. brevis 47 was transformable because it had been reported that not all species of Bacillus are capable of developing competence. ${ }^{5)}$ Experiments were done to standardize the conditions required to obtain the competent state in B. brevis 47. Homologous DNA extracted from wild type strain $B$. brevis 47 was used to transform $B$. brevis 47-5 (ura ${ }^{-}$), 47-6 $\left(\mathrm{arg}^{-}\right), 47-7\left(\mathrm{ura}^{-}\right), 47-3\left(\mathrm{lys}^{-}\right)$, and 47-12 $\left(\mathrm{arg}^{-}\right)$to prototrophy. In these studies the transformation frequency ranged from $10^{-4}-10^{-5}$ and the transformants remained stable. Strain $47-5$, which gave rise to the least spontaneous revertants, was used in subsequent experiments.

Recipient cells grown on Tryptose Blood Agar Base plates were inoculated into GM $\left(\mathrm{OD}_{660}: 0.05\right.$, or $10^{8}$ cells $/ \mathrm{ml}$ ) and incubated with vigorous shaking at $37^{\circ} \mathrm{C}$. Maximum competence was attained $1 \sim 1.5 \mathrm{hr}$ after the culture entered the stationary phase. At this time the culture was diluted 10 -fold with CM (total volume, $1.0 \mathrm{ml}$ ) and incubated further for $30 \mathrm{~min}$ at $37^{\circ} \mathrm{C}$. DNA was added at a concentration of $20 \sim 40 \mu \mathrm{g} / \mathrm{ml}$ and incubation, with shaking, was continued for $60 \mathrm{~min}$. One tenth $\mathrm{ml}$ of the mixture was plated without dilution usually on $\mathrm{T} 2$ but also sometimes on M9 plates and incubated at $30^{\circ} \mathrm{C}$.

Plates containing $0.2 \%$ starch were used for the direct selection of amylase producing colonies when donor DNA was from B. amyloliquefaciens. After $16 \sim 48 \mathrm{hr}$ incubation at $30^{\circ} \mathrm{C}$, amylase producing colonies were selected after replica plating and flooding of the original plates with $\mathrm{N} / 50 \mathrm{I}_{2}$-KI solution.

Colonies of B. amyloliquefaciens or B. subtilis are either white or pink in color, respectively, and both have a somewhat dry and flaky appearance, while colonies of the recipient $B$. brevis are creamy and translucent (see Fig. 1). Thus, when $B$. amyloliquefaciens and B. subtilis were the DNA donors it was possible to pick up the new clones directly from T2 plates owing to their prominently different morphology against the uniform background of recipient cells.

Controls without DNA and DNA sterility controls were run parallel with each experiment. When DNase treatment was done, DNA was incubated with $20 \mu \mathrm{g} / \mathrm{ml}$ DNase for $10 \mathrm{~min}$ at $37^{\circ} \mathrm{C}$.

Exoprotein assay. Cells were grown for $48 \mathrm{hr}$ at $37^{\circ} \mathrm{C}$ in
T2 medium supplemented with $0.005 \%$ uracil at which time exoprotein accumulation was maximum. Proteins secreted into the medium were precipitated with cold $5 \%$ TCA after removing the cells by centrifugation $(10,000$ $\mathrm{rpm}, 10 \mathrm{~min}, 4^{\circ} \mathrm{C}$ ). This protein, henceforth referred to as exoprotein, was determined by the method of Lowry et $a l{ }^{6)}$ using bovine serum albumin as the standard.

$S D S-P A G E$ * $^{*}$ Excess TCA was removed from the precipitated exoprotein by carefully washing the inside wall of the tubes with water without disturbing the pellet. Samples for SDS-PAGE were prepared by solubilizing the protein in buffer containing $0.0625 \mathrm{~m}$ Tris- $\mathrm{HCl}$ (pH 6.8), $2 \%$ SDS, $5 \% \beta$-mercaptoethanol and $10 \%$ glycerol, and heating at $100^{\circ} \mathrm{C}$ for $5 \mathrm{~min}$ to ensure complete dissociation of proteins. Ten $\%$ polyacylamide gels, as described by Laemmli, ${ }^{7)}$ were used and electrophoresis was done at a constant current of $30 \mathrm{~mA}$. Gels were stained with Coomassie brilliant blue according to the method of Fairbanks et al. ${ }^{8)}$ and destained in several changes of $10 \%$ acetic acid.

PAGE for $\alpha$-amylase was done according to Laemmli $^{7}$ as described above, except that SDS was omitted and gels were electrophoresed overnight at $4^{\circ} \mathrm{C}$ at a constant current of $5 \mathrm{~mA}$. Enzyme solutions were prepared by dissolving the lyophilized samples of $48 \mathrm{hr}$ culture supernatants in electrode buffer and bromophenol blue was added as the marker. Electrophoresed gels were placed on $1.5 \%$ agar plates containing $0.2 \%$ starch and incubated at $40^{\circ} \mathrm{C}$ for about $1 \mathrm{hr}$. Clear zones indicating $\alpha$-amylase activity were detected after flooding the plates with iodine solution.

Enzyme assays. $\alpha$-Amylase activity was assayed according to a modified version of the method of Fuwa, ${ }^{9)}$ using soluble starch as substrate. Hydrolysis of $0.1 \mathrm{mg}$ of soluble starch in $1 \mathrm{~min}$ at $40^{\circ} \mathrm{C}$ was defined as 1 unit of enzyme activity. Protease activity was assayed by a modification of the casein digestion method of Kunitz. ${ }^{10)}$ One unit of protease activity was arbitrarily defined as that amount of enzyme which produces an increase in $\mathrm{OD}_{275}$ of 0.001 in $40 \mathrm{~min}$ at $35^{\circ} \mathrm{C}$. RNase was assayed according to the method of Schucher and Hokin ${ }^{11)}$ using yeast RNA as substrate. One unit of the enzyme activity was arbitrarily defined as that amount of enzyme which under the given conditions produces an increase in $\mathrm{OD}_{260}$ of 0.001 in 30 $\min$ at $38^{\circ} \mathrm{C}$.

A portion of the $48 \mathrm{hr}$ culture supernatant, suitably diluted with the same buffer as that in the reaction mixture, was used as the enzyme solution in each case.

Chemicals. Bacto Tryptose Blood Agar Base (dehydrated), soluble starch and casamino acids were from

* Abbreviations: TCA, trichloroacetic acid; SDS, sodium dodecyl sulfate; PAGE, polyacrylamide gel electrophoresis. 
Difco Laboratories, casein nach Hammersten from Merck, and yeast RNA from P-L Biochemicals, Inc. DNase was from Worthington Biochemical Corp. All other reagents used were of analytical grade.

\section{RESULTS}

\section{Isolation of new clones}

After repeated transformation experiments described in Materials and Methods, about 80 transformant-like colonies were isolated and purified to homogeneity. The competent state in B. brevis 47-5, if it exists at all, seemed very transitory. Judging from the extremely low frequency of transformation (probably less than $10^{-7}$ ), only a small population in the recipient cells appears to become competent for DNA uptake. This low frequency (on average two or three colonies per plate) made it difficult to verify that the appearance of the new colonies was in fact the result of DNA mediated transformation. However, the possibility that they were contaminants from external sources was excluded because the DNA solutions were sterile and no transformant-like colonies ever appeared on control plates without DNA or with DNA pretreated with DNase.

Many of the transformant-like colonies segregated morphologically into recipient or donor type cells after repeated streakings onto fresh nutrient plates or even on prolonged keeping at room temperature (a few days to a week). Often, amylase productivity of the transformant-like cells was lost after several single colony isolation procedures.

Therefore, only those clones that remained stable after repeated transfers $(3 \sim 5$ times $)$ were purified by single colony isolation. and used for further studies.

\section{Properties of isolated clones}

Table I gives a summary of properties of the new clones. For brevity, the characteristics of only a few representative clones have been given. Including the ones not shown in the Table, every clone isolated was different from the recipient and the donor in some of its properties.

Morphology: Based on morphology the new clones were classified into three types: (a) those resembling the recipient strain, B. brevis 47-5, i.e., yellowish color with a moist and translucent appearance (e.g., AM29 in Fig. 1), (b) those resembling the donor strains, B. amyloliquefaciens or B. subtilis, i.e., whitish or pink color, respectively, with a dry and flaky appearance (e.g., AM1 and AM5 in Fig. 1) and (c) new types intermediate in morphology between the two parents, i.e., yellowish white and dry, or pinkish and creamy, etc. (e.g., AM4

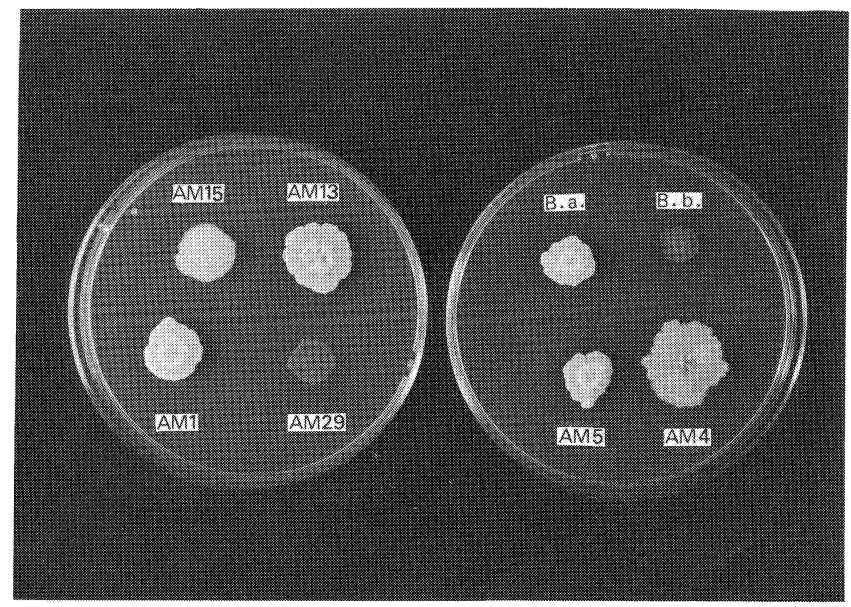

FIG. 1. Colonial Morphology of Parents and Some New Clones.

Bacteria were grown on $\mathrm{T} 2$ plates containing uracil at $37^{\circ} \mathrm{C}$ for $48 \mathrm{hr}$. See text for a detailed explanation and the legends of Figs. 2, 3 and 4 for the meanings of the symbols. 
Table I. Characteristics of Some Representative Clones

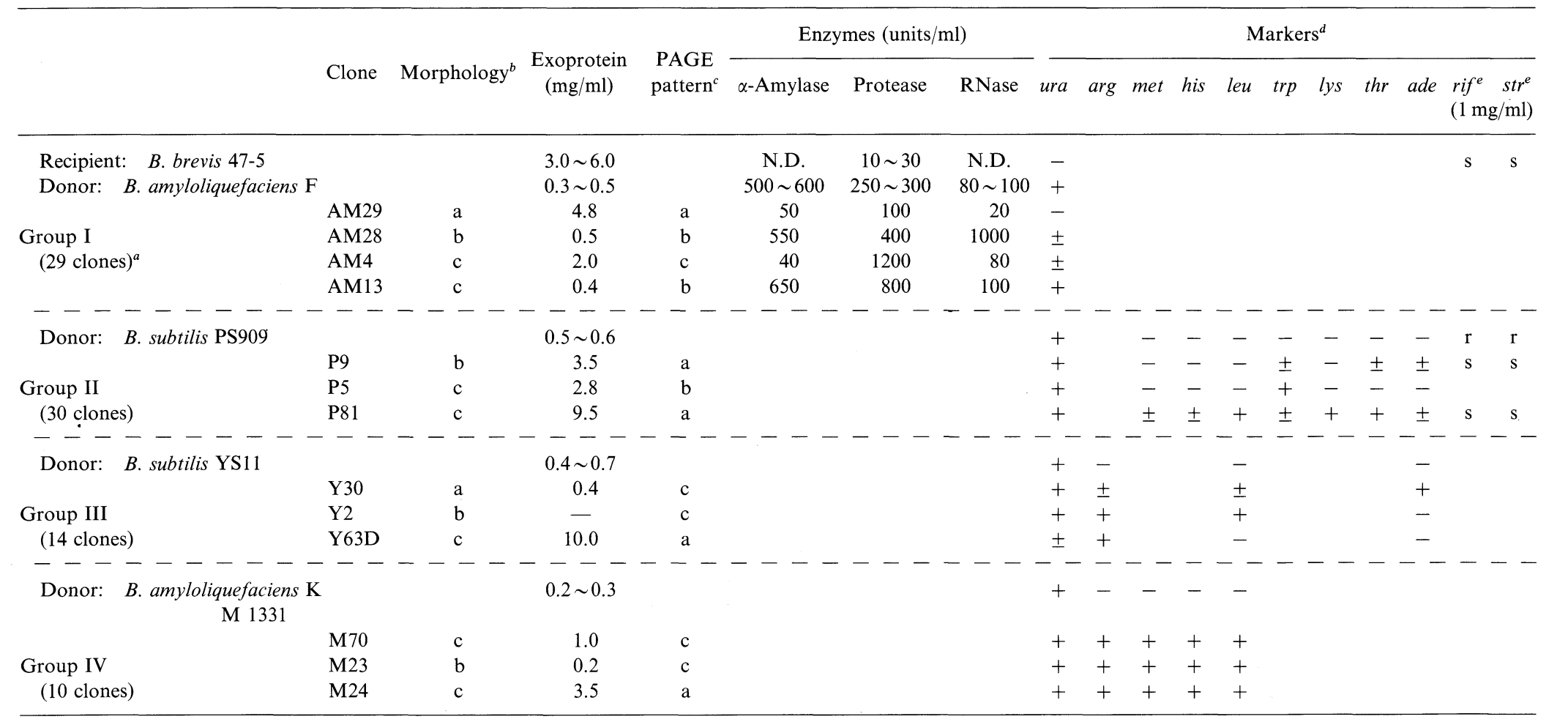

${ }^{a}$ Total number of clones isolated in each group.

${ }^{b}$ a, resembling the recipient; $b$, resembling the donor; $c$, new type intermediate between parents (see text for explanation).

c Symbols same as in b. See Figs. 2, 3 and 4 for reference.

${ }^{d} \pm$ indicates that the nutrient requirement is leaky.

e s, sensitive; r, resistant.

N.D., not detected. 


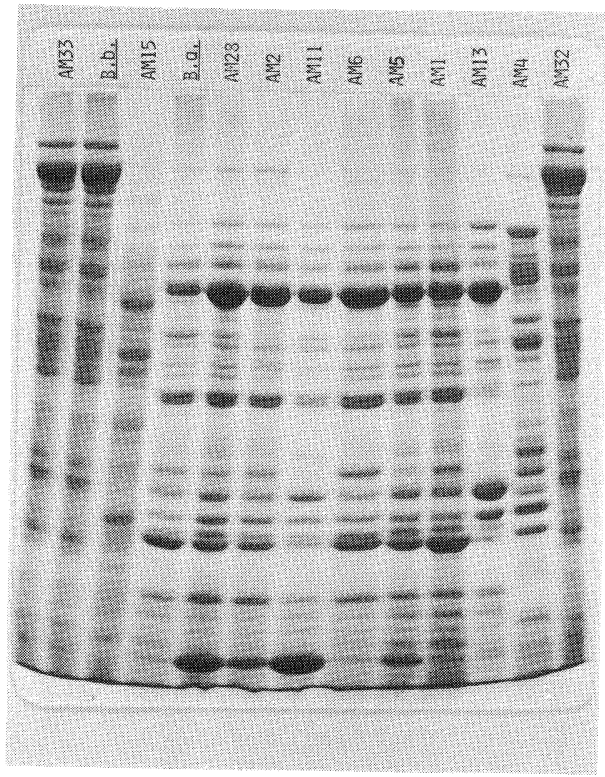

FIG. 2.

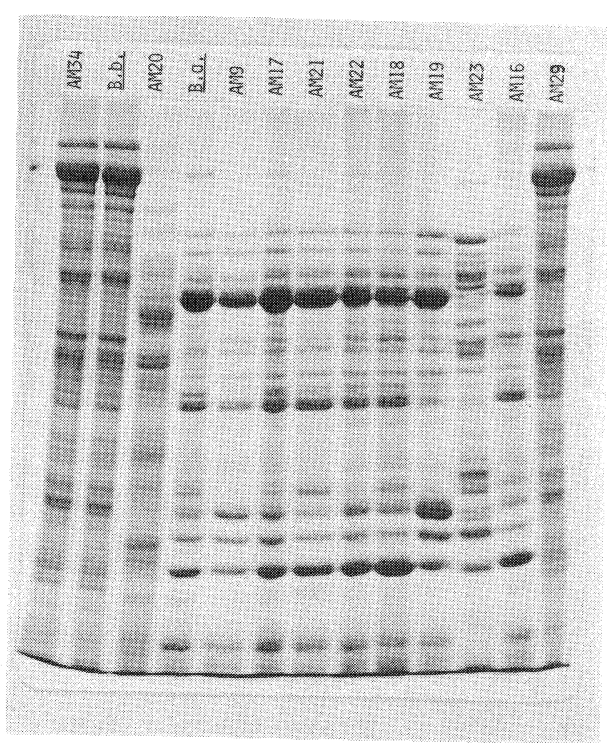

FIG. 3.

and AM15 in Fig. 1).

Out of the total of about 30 clones isolated for each of groups I and II in Table I, where the DNA donors were $B$. amyloliquefaciens $\mathrm{F}$ and $B$. subtilis PS909, respectively, almost half in each group were of type (b), i.e., resembled the donors in morphology and the rest resembled either the recipient, type (a), or had a new kind of morphology intermediate between those of the two parents, i.e., type (c). But out

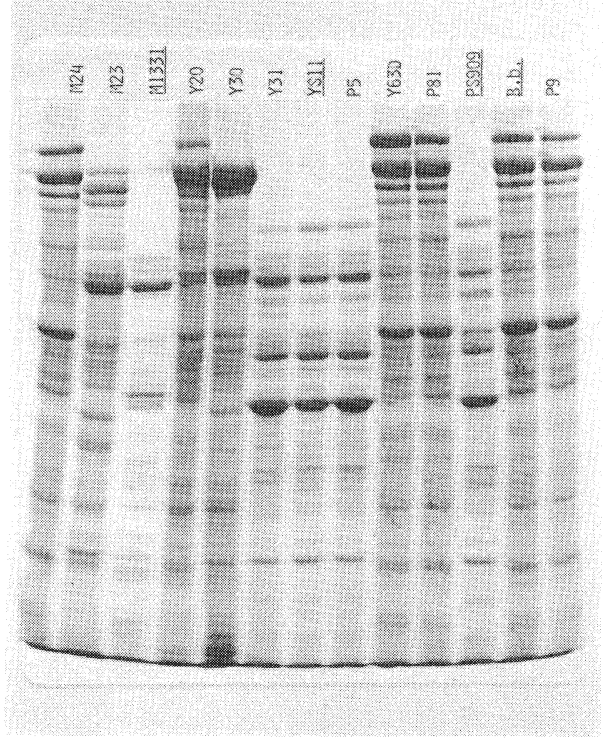

FIG. 4.

FIGS. 2, 3 and 4. SDS-PAGE of Exoproteins.

Equal amounts of proteins $(40 \sim 50 \mu \mathrm{g})$ were applied to each slot. Numbers with a lettered prefix denote the various new clones obtained through the transformation procedure with DNA from different donors. The abbreviations for the recipient and donor strains are shown below with the respective prefix for the new clones indicated in brackets. B.b., B. brevis 47-5; B.a., B. amyloliquefaciens F (AM); PS909, B. subtilis PS909 (P); YS11, B. subtilis YS11 (Y); M1331, B. amyloliquefaciens K M1331 (M). Recipient and donor strains have been underlined for clarity.

of the total of 14 and 10 clones isolated, respectively, for groups III and IV, about 8 in each group had an intermediate or type (c) morphology and the rest had either type (a) or type (b) morphology.

Exoprotein Production: When the recipient, $B$. brevis 47-5, was grown in $\mathrm{T} 2$ medium with uracil for $48 \mathrm{hr}$ at $37^{\circ} \mathrm{C}, 3 \sim 6 \mathrm{mg} / \mathrm{ml}$ of TCA precipitable protein could be obtained from the culture supernatant. The donor strains of B. subtilis and B. amyloliquefaciens, on the other hand, produced only a little exoproteins, $0.3 \sim 0.7 \mathrm{mg} / \mathrm{ml}$. With a few exceptions, the amount of exoproteins produced by the new clones was correlated to their colonial morphology, i.e., for clones with type (a) morphology exoprotein production was in the range produced by the recipient, i.e., $3 \sim 6$ 
$\mathrm{mg} / \mathrm{ml}$, and for those with type (b) morphology it was $0.2 \sim 0.7 \mathrm{mg} / \mathrm{ml}$. For clones with type (c) morphology exoprotein production was either in the same range as that of the parents or in an intermediate range of $1 \sim 2$ $\mathrm{mg} / \mathrm{ml}$, but in some instances, such as clone P81 or Y63D (Table I), protein production was almost double that of B. brevis 47-5, i.e., about $10 \mathrm{mg} / \mathrm{ml}$. At least 4 other clones showed comparably high exoprotein production (not shown in Table).

$S D S-P A G E$ : SDS-PAGE patterns of the exoproteins are shown in Figs. 2, 3 and 4. The majority of the isolates had exoprotein patterns resembling the donor strain, while some resembled the recipient strain. In a few cases, e.g., AM4, AM15 in Fig. 2, and AM20, AM23 in Fig. 3, the exoprotein patterns appeared intermediate between the donor and recipient types. AM4 and AM15 also exhibited intermediate colonial morphology (see Fig. 1). Both clones AM4 and AM13 (shown in Fig. 2) while exhibiting an exoprotein pattern somewhat different from the donor also had $3 \sim 4$ times higher protease activity than the donor (Table I). Protein patterns of P81, Y63D and M24 in Fig. 4 are similar to that of the recipient, although these three isolates have a colonial morphology very different from the recipient (not shown). Also, as mentioned earlier, the protein productivity of P81 and Y63D is almost double that of B. brevis 47-5 (Table I). In comparison with the protein patterns of the parents, B. brevis 47-5 and B. amyloliquefaciens $\mathrm{F}$, some of the clones shown in Figs. 2, 3 and 4 had protein bands which appeared very dense, or conversely very faint, while in a few others the complete absence of certain protein bands was observed.

Genetic markers: Table I shows the appearance of the different auxotrophic and drug resistance markers in the new clones. Bott and Wilson minimal medium plates (11) were used for the examination of markers. A variety of recombinant types were obtained among the new clones. Uracil auxotrophy, the recipient marker, was not retained by most of the clones examined. There were, however, a few excep- tions which retained ura $^{-}$such as AM29 in group I in Table I. In some clones, indicated in the Table as \pm , the uracil auxotrophy was leaky and growth was very slow on nutrient plates without uracil. In group II certain clones such as P9 retained the same sensitivity to rifampicin and streptomycin as the recipient, while being morphologically similar to the donor, B. subtilis PS909, which is resistant to these drugs. In both groups II and III several donor nutrient requirement markers were introduced into the new clones such as in P5 and Y2, while some of the requirements appeared to be leaky in clones such as P81 and Y30. In group IV, however, all the clones examined were prototrophs.

Enzyme Production: Activities of extracellular enzymes such as $\alpha$-amylase, protease and RNase were assayed in the culture supernatants of the 29 clones included in group I in Table I. Diverse combinations in regard to the activities of these enzymes were obtained among the isolates which were grouped on the basis of the levels of activities of the three enzymes. Enzyme activities for only a selected few are shown in Table I as examples. Although most of the clones produced enzymes in the same range or lower than that of the donor, B. amyloliquefaciens $\mathrm{F}$, in a few exceptional cases the enzyme activities were many fold higher. For instance, RNase activity in AM28 and protease activities in both AM4 and AM13 were very high.

The recipient, B. brevis 47-5, does not produce either extracellular $\alpha$-amylase or RNase, but low levels of $\alpha$-amylase and RNase activities were detected in AM29 which is otherwise similar in morphology and protein pattern on PAGE to B. brevis 47-5 (Figs. 1 and 3).

Several of the high enzyme producing clones were compared with the donor, B. amyloliquefaciens $\mathrm{F}$, in regard to the time course of production, $\mathrm{pH}$ optima and heat inactivation patterns of $\alpha$-amylase and protease. In almost all cases the enzymes behaved identically to that of the donor. Only in two exceptional cases, AM4 and AM13, the enzymes showed anomalous behavior and the results are shown 
in Figs. 5, 6 and 7.

Figure 5 shows the time course of $\alpha$-amylase and protease production. The peaks of $\alpha$ amylase and protease production in B. amyloliquefaciens and most of the new clones examined were at $30 \mathrm{hr}$ and $20 \mathrm{hr}$ of growth, respectively. Among the exceptions was AM4 which showed a peak of protease production at $40 \mathrm{hr}$ and also interestingly possessed 4-fold higher protease activity than $B$. amyloliquefaciens F. AM4 is also morphologically different from either parent and showed an exoprotein pattern on SDS-PAGE (Fig. 2) which was intermediate between those of $B$. brevis and B. amyloliquefaciens $\mathrm{F}$.

Figure 6 shows the $\mathrm{pH}$ optima for $\alpha$-amylase and protease activities. All clones examined showed a $\mathrm{pH}$ optimum for $\alpha$-amylase activity of 6.0 which was similar to that of the donor, B. amyloliquefaciens $\mathrm{F}$. The $\mathrm{pH}$ optimum for protease activity in the recipient, $B$. brevis, was difficult to ascertain because of the very low

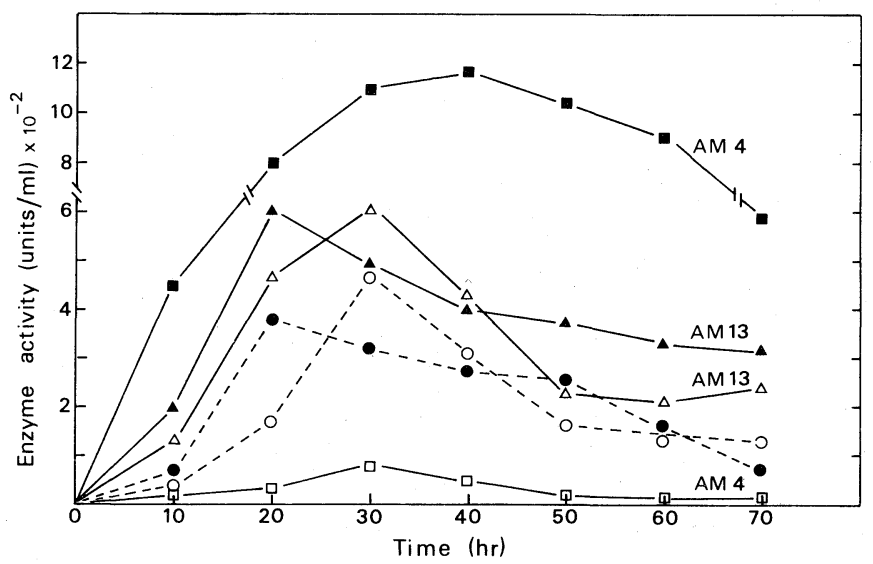

FIG. 5. Time Course of Enzyme Production.

Bacteria (strain number indicated in the figure) were cultivated in $\mathrm{T} 2$ medium aerobically at $37^{\circ} \mathrm{C}$. Other conditions and enzyme assays were as described in MATERIALS AND METHODS. Dashed lines represent enzyme production by $B$. amyloliquefaciens $\mathrm{F}$ which was used as DNA donor. $\alpha$-amylase, open symbols; protease, closed symbols.

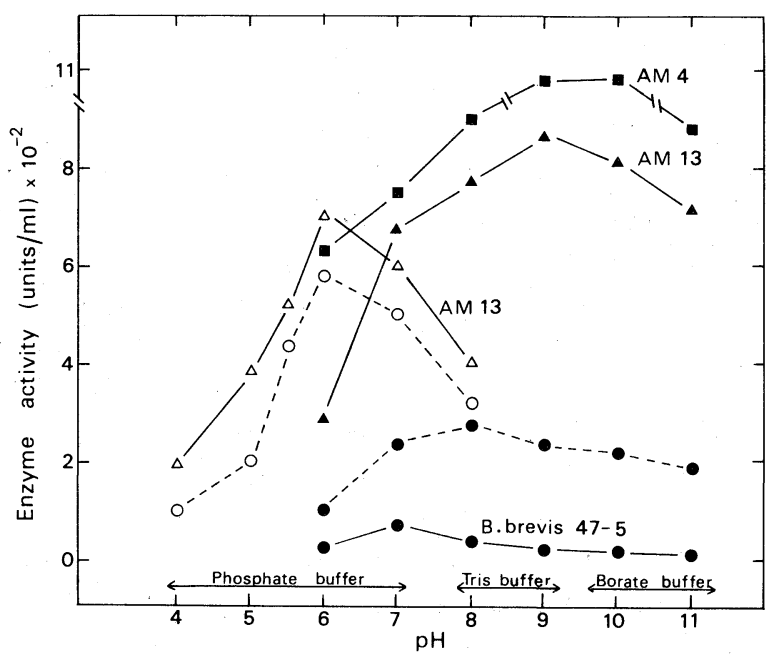

FIG. 6. Effect of pH on Enzyme Activity.

Cultural conditions and symbols are same as those in Fig. 5. All buffers used were $0.1 \mathrm{M}$. 


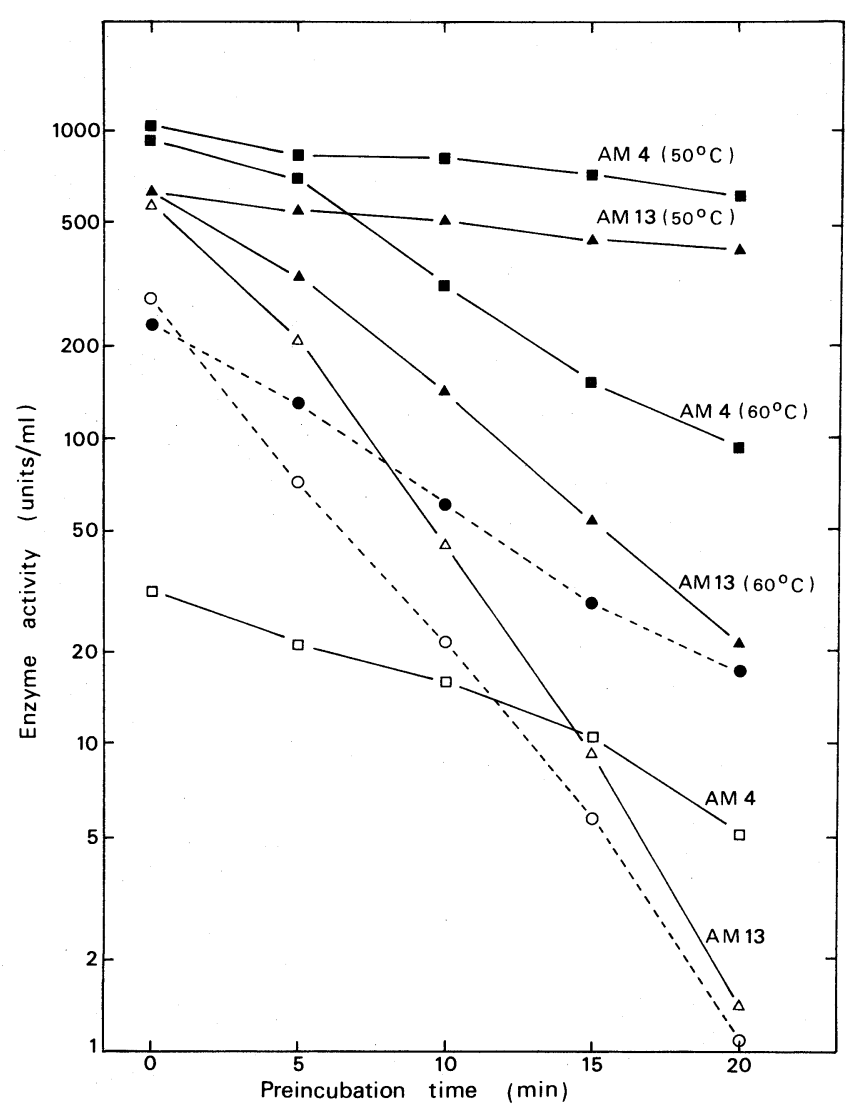

FIG. 7. Thermostability of Enzymes.

This figure shows heat inactivation curves for extracellular $\alpha$-amylase (open symbols) at $60^{\circ} \mathrm{C}$ and protease (closed symbols) at $50^{\circ} \mathrm{C}$ and $60^{\circ} \mathrm{C}$. Dashed lines represent DNA donor strain B. amyloliquefaciens $\mathrm{F}$. Culture supernatants were suitably diluted and incubated at $50^{\circ} \mathrm{C}$ or $60^{\circ} \mathrm{C}$ for the indicated time before addition of substrate. Enzyme activity was measured as described in MATERIALS AND METHODS.

activity of the enzyme. However, in B. amyloliquefaciens $\mathrm{F}$ the protease activity remained almost uniform in a broad $\mathrm{pH}$ range $(7 \sim 11)$. Similar was the case with almost all the clones examined. But in clones AM4 and AM13 in Fig. 6, the pH optima for protease activity, although not sharp, appeared to be in the range of $9 \sim 10$.

The heat inactivation curves for $\alpha$-amylase and protease are shown in Fig. 7. In AM13, which was one of the high $\alpha$-amylase producers, nearly all the enzyme activity was lost if the enzyme solution was preincubated at $60^{\circ} \mathrm{C}$ for $20 \mathrm{~min}$, whereas in $\mathrm{AM} 4$, which was one of the low $\alpha$-amylase producers, about $15 \%$ of the initial enzyme activity was retained.
For both these clones the protease activity remained stable even after 20 min preincubation at $50^{\circ} \mathrm{C}$, but a steady decline in activity was observed at $60^{\circ} \mathrm{C}$. In the donor, B. amyloliquefaciens $\mathrm{F}$, however, protease activity showed a steady decline both at $50^{\circ} \mathrm{C}$ and at $60^{\circ} \mathrm{C}$ (curve for only $50^{\circ} \mathrm{C}$ shown in Fig. 7).

The $\alpha$-amylases of AM4 and AM13 were also compared with that of the donor, $B$. amyloliquefaciens, by electrophoresis on polyacrylamide gels as described in Materials and Methods. The gel profiles showed that the $\alpha$-amylases of AM4 and AM13 migrated to the same position as that of the donor.

Although the $\alpha$-amylases of AM4 and 
AM13 were electrophoretically identical to that of the donor, the results in Figs. 5, 6 and 7 show that both $\alpha$-amylases and proteases were different in some of their properties, e.g., $\mathrm{pH}$ optima or heat inactivation pattern. It is, therefore, tempting to speculate that genetic recombination may have brought about certain alterations in the enzyme proteins. However, the nature of these changes remains to be elucidated.

\section{DISCUSSION}

In transformation experiments with homologous DNA, competent cells in B. brevis 47 were obtained only during a certain phase of growth. Even under conditions optimal for transformation with homologous DNA it was found extremely difficult to obtain transformants with heterologous DNA. However, with the procedure described in this paper we were able to obtain about 80 clones with new phenotypes from an enormously large number of $B$. brevis 47 cells treated with heterologous DNA.

Some of the new clones were similar to the recipient cells accompanied by some alterations in properties such as morphology and protein production. Some were of an intermediate type with characteristics of both recipient and donor cells. Even clones exhibiting characteristics of DNA donor cells, in regard to morphology, genetic markers and enzyme production, were found. Included among these were clones which exhibited either donor or intermediate type morphology, but showed enzyme activities which were much higher than those of the donor.

However, transformation in so many traits at one time is unusual and has probably not been reported before in bacteria. From the known mechanism of transformation it is difficult to understand that so much genome of the recipient bacteria is replaced by externally added donor DNA. We suspected firstly that the donor DNA preparation was contaminated with viable spores of the donor strain, but we could not find any spores. Actually new clones were obtained only during a limited period of competence in the growth phase (at about the same time of competence as for homologous DNA) and they never appeared without DNA addition. Often, segregation of purified colonies was very conspicuous. All these data strongly suggest that many of the new clones, if not all, were generated through mediation of heterologous DNA.

A possible explanation for the phenomena described in this report may be as follows. $B$. brevis cells could have a special feature in that only a very small fraction of a large cell population becomes competent to incorporate many DNA molecules into one cell. Incorporated DNA molecules either persisted along with the recipient chromosome, or linked to form a replicon. Either extensive recombination or exchange of large segments between the two kinds of DNA might have occurred in the cells. Thus, even DNA donorlike cells sometimes appeared after segregation. On the other hand, it is possible, although unlikely, that some clones might have resulted from spontaneous mutations. Still other possibilities cannot be neglected. Non-viable, but still intact cells in the DNA preparation of the donor bacteria may have fused with the recipient cells to yield a donor type bacterium.

The temporary coexistence of DNA other than plasmid DNA and chromosomal DNA is known, in phenomena such as "heterocaryosis"12) or "pseudolysogeny"13) in bacteria belonging to the genus Bacillus. Concurrent transformation of $E$. coli by a selected and an unselected plasmid at high frequency, ${ }^{14)}$ and introduction into mammalian cells of many unselected genes simultaneously with the transfer of one selected marker DNA $^{15,16)}$ have also been reported. These various observations in the literature may have some relevance to our finding and suggest that occurrence of the unusual phenomena reported in this paper is not unlikely. Nevertheless, the results shown here can not be explained by the previously known mechanism of transformation and might imply a new type 
of gene transfer.

Unlike other Bacillus sp., B. brevis has a characteristic cell surface structure, i.e., a cell wall consisting of a thin peptidoglycan and two protein layers. ${ }^{17)}$ Therefore it would be interesting to clarify the mechanism of gene transfer in this bacterium.

Among the interesting and possibly useful clones obtained through these experiments were, for instance, P81 and Y63D with very high protein productivity, and AM4 and AM28 which have many fold higher protease and RNase activities than the parent strains. The results, therefore, show the usefulness of the procedure described in this paper for obtaining bacteria of new phenotypes.

Acknowledgments. The authors wish to thank Dr. H. Saito for kindly supplying the bacterial strains and for useful discussions. I. H. was the recipient of a scholarship from the Ishizaka Foundation, Tokyo.

\section{REFERENCES}

1) S. Udaka, Agric. Biol. Chem., 40, 523 (1976).

2) T. Tsuchida, S. Miyashiro, H. Enei and S. Udaka, Agric. Biol. Chem., 44, 2291 (1980).
3) I. Mahler, "Methods in Enzymology," Vol. XII B, ed. by L. Grossman and K. Moldave, Academic Press, New York, London, 1968, p. 846.

4) H. Saito and K.-I. Miura, Biochim. Biophys. Acta, 72, 619 (1963).

5) K. F. Bott and G. A. Wilson, Bacteriol. Rev., 32, 370 (1968).

6) O. H. Lowry, N. J. Rosebrough, A. L. Farr and R. J. Randall, J. Biol. Chem., 193, 265 (1951).

7) U. K. Laemmli, Nature, 227, 680 (1970).

8) G. Fairbanks, T. L. Steck and D. F. H. Wallach, Biochem., 10, 2606 (1971).

9) K. Yamaguchi, H. Matsuzaki and B. Maruo, J. Gen. Appl. Microbiol., 15, 97 (1969).

10) B. K. May and W. H. Elliot, Biochim. Biophys. Acta, 157, 607 (1968).

11) R. Schucher and L. E. Hokin, J. Biol. Chem., 210 , 551 (1954).

12) Y. Ikeda and T. Iijima, J. Bacteriol., 83, 1025 (1962).

13) H. E. Hemphill and H. R. Whiteley, Bacteriol. Rev., 39, 257 (1975).

14) P. J. Kretschner, A. C. Y. Chang and S. N. Cohen, J. Bacteriol., 124, 225 (1975).

15) N. Hsiung, H. Warrick, J. K. DeReil, D. Tuen, B. J. Forget, A. Skoultchi and R. Kucherlapati, Proc. Natl. Acad. Sci. U.S.A., 77, 4852 (1980).

16) M. Wigler, R. Sweet, G. K. Sim, B. Wold, A. Pellicer, E. Lacy, T. Maniatis, S. Silverstein and R. Axel, Cell, 16, 777 (1979).

17) H. Yamada, N. Tsukagoshi and S. Udaka, J. Bacteriol., 148, 322 (1981). 